\section{Uji Hemaglutinasi Assay pada Hemolimf Spodoptera exigua yang diberi Perlakuan Botani Pestisida}

\author{
A.Irma Suryani \\ Tjandra Anggraeni
}

\begin{abstract}
Abstrak. Tahap larva dari ulat grayak (Spodoptera exigua), memiliki aktifitas makan yang tinggi dan bersifat polifagus sehingga serangga ini berpotensi sebagai hama dalam pertanian. Penggunaan botani pestisida dalam hal ini Mirabilis jalapa, diharapkan dapat mengendalikan hama pertanian sehingga dilakukan penelitian terhadap imun sistem larva S. exigua dengan mengamati lektin yang berperan dalam menganali molekul asing yang masuk ke tubuh serangga. Hasil penelitian diperoleh, semakin tinggi konsentrasi M. jalapa, pada konsentrasi M. jalapa 0.4\% dan 0.8\%, maka titer agglutinasi hemolimf semakin rendah. Hal ini diduga daya ikat lektin terhadap molekul asing semakin menurun. Sehingga M. jalapa ini berpotensi dimanfaatkan sebagai botani pestisida yang ramah lingkungan.

Kata kunci: hama pertanian, botani pestisida, agglutinasi lektin.
\end{abstract}

\section{Pendahuluan}

Molekul asing yang masuk ke tubuh serangga akan direspon oleh imun sistem. Lektin berperan penting dalam memperantarai pengenalan non-self dari imun innate diantaranya dalam opsonisasi (Wilson et al., 1999). Lektin (agglutinin) terdapat dalam bentuk larutan ataupun terikat pada membran.

Lektin merupakan salah satu imun humoral berupa dimana, agglutinin atau lektin ini merupakan molekul berupa protein bukan enzim yang berikatan atau bereaksi dengan karbohidrat dari partikel asing yang dapat menyebabkan aglutinasi atau presipitasi sehingga lektin ini berperan sebagai pengenalan sel asing yang masuk ke dalam tubuh organisme khususnya serangga (Narayanan, 2004, Anggraeni, 1992). Mekanisme pengikatan lektin terhadap karbohidrat berupa ikatan non kovalen. Ikatan ini tergolong lemah, tapi jika terbentuk lebih dari satu ikatan, baik antar molekul maupun di dalam molekul lektin, maka cukup kuat untuk menggumpalkan lektin (Altroy, 1988 dalam Harjono, 1996). Lektin selain berperan dalam pengenalan non-self, juga diketahui berperan dalam opsonisasi fagositosis (Wilson et al., 1999). Menurut (Sharon, 1984 dalam Anggraeni 1992), terdapat tiga interaksi lektin yang terjadi yaitu: (i) antara gula pada permukaan fagosit dan lektin dari permukaan sel lain; (ii) antara lektin pada permukaan fagosit dan gula dari permukaan sel yang lain (atau partikel); (iii) dengan cara ekstraseluler lektin yang membentuk jembatan antara gula pada kedua tipe sel. Lektin yang terdapat pada

\section{BIONATURE}

p-ISSN 1411 - 4720

e-ISSN 2654 - 5160

Abstract. The larval stage of the armyworm (Spodoptera exigua), has a high and polyphagous feeding activity so that these insects have the potential to be pests in agriculture. The use of botanical pesticides in this case Mirabilis jalapa, is expected to control agricultural pests so that research on the immune system of $S$. exigua larvae is carried out by observing lectins that play a role in analyzing foreign molecules that enter the insect's body. The results were obtained, the higher the M. jalapa concentration, at the concentration of M. jalapa $0.4 \%$ and

$0.8 \%$, the lower the hemolymf agglutination titers. This is thought to decrease the binding capacity of lectins to foreign molecules. So that M. jalapa has the potential to be used as an environmentally friendly botanical pesticide

Keywords: agricultural pests, botanical pesticides, lectin agglutination.

A.Irma Suryani

Universitas Negeri Makassar Indonesia

Tjandra Anggraeni Institut Teknologi Bandung Indonesia 
hewan maupun tumbuhan, memiliki spesifitas yang berbeda-beda misalnya pada kecoak, spesifik terhadap GalNac dan fukosa, Bombyx sp (asam glukuronat), S. exigua (galaktosa), ayam (mannosa), manusia (glukosa-galaktosa), kacang ercis ( $\alpha$ mannosa) (Boucias dan Pendland, 1993: Harjono, 1996).

Lektin pada bangsa lalat Sarcophaga peregrina meskipun terdeteksi pada permukaan beberapa hemosit, plasmatosit dan granulosit, lektin ini disintesa oleh badan lemak yang kemudian dilepaskan ke hemolimf (Komano, 1983 dalam Anggraeni, 1992). Uji Hemagglutinasi ini dengan menggunakan beberapa eritrosit vertebrata. Dikarenakan lektin invertebrata teragglutinasi terhadap molekul asing secara in vitro dengan menggunakan eritrosit vertebrata (Gul dan Avyali, 2001). Pada penelitian ini digunakan eritrosit vertebrata (kelinci) dan dilakukan pengamatan terhadap titer agglutinasi hemolimf $S$. exigua yang telah diberi perlakuan M.jalapa.

\section{Metode Penelitian}

\section{Prosedur Penelitian}

Larva S. exigua instar 3, didinginkan terlebih dahulu \pm 10 menit sebelum hemolimfnya diambil. Prosesnya sebagai berikut:

a. Larva S. exigua diambil hemolimfnya dengan pipa kapiler. Hemolimf yang keluar dari setiap larva segera dikumpulkan ke dalam mikrotube (eppendorf) berukuran 1,5 ml yang berisi beberapa kristal phenylthiourea. Seluruh hemolimf disentrifuge pada kecepatan $8000 \mathrm{~g}$, suhu $4^{\circ} \mathrm{C}$, selama 5 menit. Supernatan digunakan untuk hemagglutinasi assay (HA).

b. Pelet yang dihasilkan, dicuci tanpa disuspensikan dengan menggunakan TBS, pH 7,4 kemudian disuspensikan hanya dengan menggunakan $50 \mu \mathrm{l} \mathrm{TBS,} \mathrm{pH} \mathrm{7,} \mathrm{Pelet} \mathrm{diresuspensikan}$ dengan menggunakan mikropipet dan disentrifugasi pada kecepatan $12.000 \mathrm{~g}$, suhu $4{ }^{\circ} \mathrm{C}$, selama 15 menit. Lisat yang dihasilkan dipergunakan untuk assay HA.

c. Hemagglutinasi assay (HA) dilakukan pada microplate, 96, ' $\mathrm{V}$ '

d. Dilakukan pengenceran seri, sampel yang diuji sebanyak $25 \mu \mathrm{l}$ dibuat di dalam TBS (pH 7,4) pada microplate.

e. Sebanyak $25 \mu \mathrm{l}$ suspensi eritrosit kelinci (trisodium sitrat), (eritrosit tersebut telah dicuci $3 x$ dengan menggunakan TBS, pH 7 dan diresuspensi dengan buffer yang sama) ditambahkan ke larutan yang telah diencerkan tadi.

f. Campuran tersebut kemudian diinkubasi pada temperatur ruangan selama 60 menit, setelah itu diamati lektin yang membentuk roset. Metode kerja merupakan modifikasi dari buku petunjuk laboratorium (Anggraeni, 1992).

\section{Hasil Penelitian}

Tabel 1. Perhitungan Titer Agglutinasi

\begin{tabular}{|c|c|c|c|}
\hline \multirow[b]{2}{*}{$\begin{array}{c}\text { Eritrosit } \\
\text { vertebrata }\end{array}$} & \multirow[b]{2}{*}{$\begin{array}{c}\text { Perlakuan Larva } \\
\text { diberi MJ (\%) }\end{array}$} & \multicolumn{2}{|c|}{ Titer Aglutinasi $S$. exigua } \\
\hline & & supernatan larva & pelet larva \\
\hline \multirow{5}{*}{ Kelinci } & 0 & 64 & 6 \\
\hline & 0.1 & 64 & 4 \\
\hline & 0.2 & 32 & 4 \\
\hline & 0.4 & 16 & 2 \\
\hline & 0.8 & 16 & 0 \\
\hline
\end{tabular}

Berdasarkan tabel diatas, hasil uji HA diperoleh titer agglutinasi tertinggi dari uji menggunakan eritrosit vertebrata, dikarenakan lektin invertebrata (serangga) teragglutinasi terhadap molekul asing secara in vitro dengan menggunakan eritrosit vertebrata (Gul dan 
Avyali, 2001). Dalam penelitian ini digunakan eritrosit kelinci karena hal ini sejalan dengan penelitian Gomes et al., (1988) yang meneliti aktifitas natural lektin pada hemolimf Pangstrongylus megistus melalui uji hemagglutinasi, menemukan bahwa pada supernatan dan pelet $P$. megistus terdapat aktifitas lektin dimana, titer hemagglutinasi tertinggi diperoleh dari hasil uji eritrosit kelinci.

Hasil uji hemagglutinasi diketahui bahwa baik dalam kondisi normal maupun pada perlakuan M. jalapa, lektin ini dapat terdeteksi namun hasil titer aglutinasi pada perlakuan dengan konsentrasi $0.1 \%$ dan $0.2 \%$ lebih tinggi dan terjadi penurunan titer agglutinasi pada konsentrasi $0.4 \%$ dan $0.8 \%$ seperti halnya yang terjadi pada pengamatan respon imun seluler (hemosit). Selain itu, titer agglutinasi pada supernatan lebih tinggi dibanding pada pelet, diduga karena sintesa lektin terjadi di badan lemak dan dilepaskan ke hemolimf serangga sehingga akumulasi lektin lebih dominan pada plasma atau supernatan serangga.

Penurunan aktifitas lektin dari hasil uji titer agglutinasi. Semakin tinggi konsentrasi M.jalapa yang digunakan, maka semakin rendah titer aglutinasi hemolimf S.exigua. Hal ini diduga, daya ikat lektin dalam mengenali molekul asing semakin berkurang sehingga, M.jalapa ini berpotensi digunakan sebagai botani pestisida di masa akan datang.

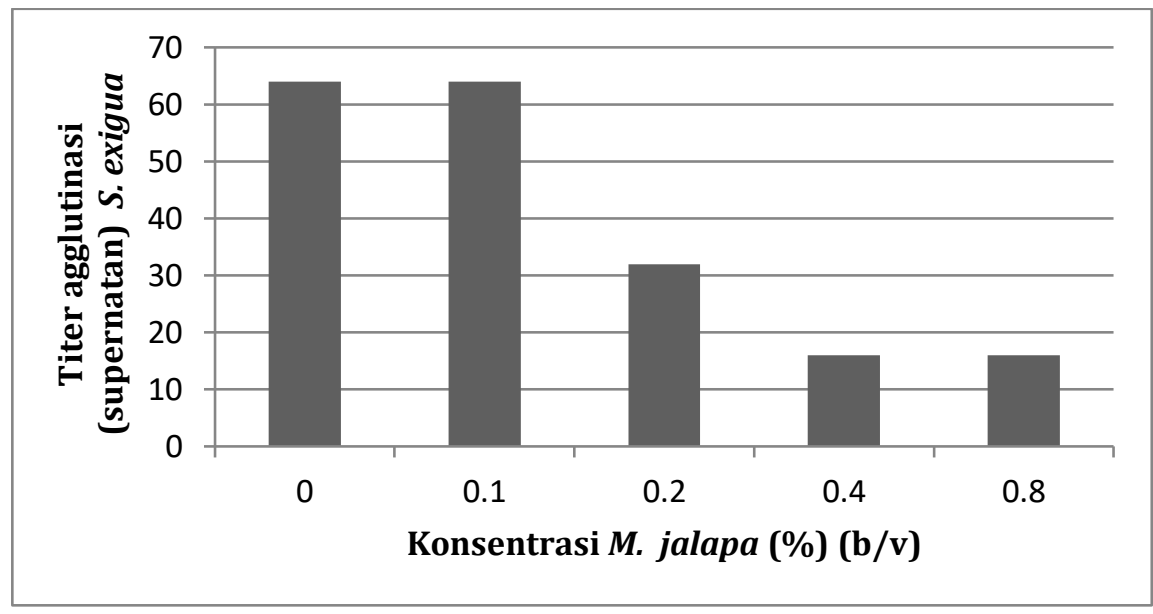

Gambar 1. Pemberian M. jalapa terhadap Penurunan Titer Agglutinasi pada Supernatan Larva S. Exigua Menggunakan Eritrosit Vertebrata (Kelinci)

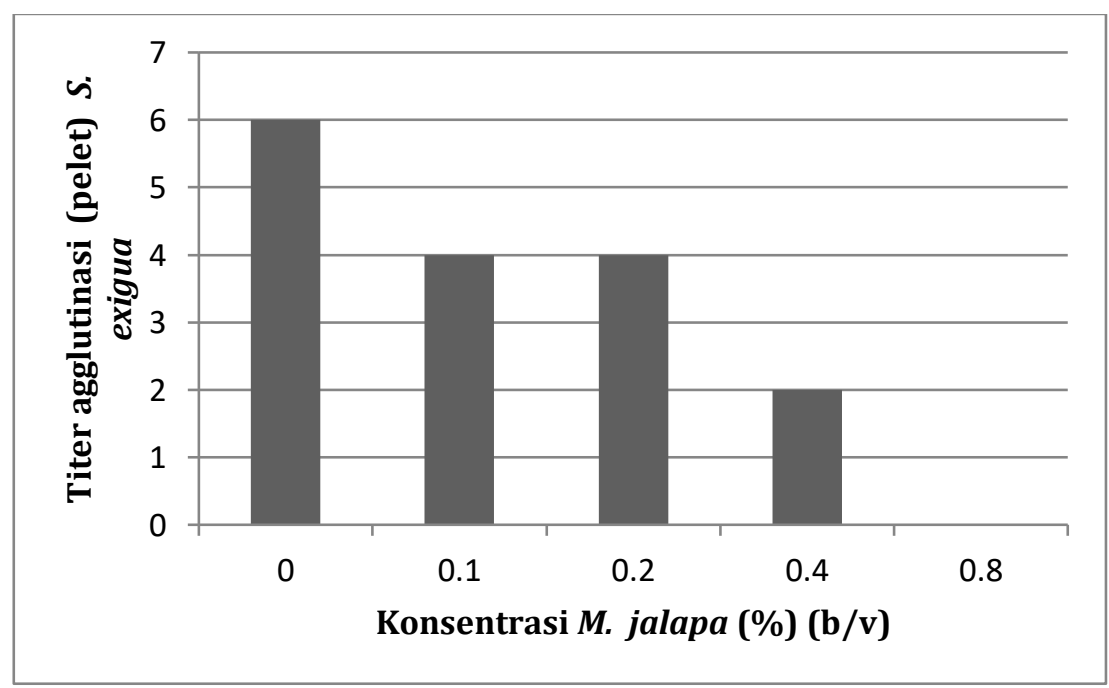

Gambar 2. Pemberian M. jalapa terhadap Penurunan Titer Agglutinasi pada Pelet Larva S. Exigua Menggunakan Eritrosit Vertebrata (Kelinci) 


\section{Referensi}

Anggraeni, T.(1992). Sistem Pertahanan Tubuh pada Serangga. PAU Bidang Ilmu Hayati. Bandung.

Boucias, Pendland. (1993). The Galactose Binding Lectin from The Beet Armyworm, Spodoptera exigua. Journal Insect Biochemistry and Molecular, 23 (2), 233-42.

Gomes, Y.M., Furtado, A.F., Carvalho, A.B.D. (1988). Natural Lectin Activity in the Haemolymph of Pangstrongylus megistus (Heteroptera Reduviidae). Mem Inst Oswaldo Cruz, 83 (4), 509-12.

Gul, Avyali. (2001). Purification and Determination of the Molecular Structure of Hemolymph Lectin of Agrotis segetum (Denis and Schiff). Turk Journal Biologi, (26), 49-55.

Harjono, I.U. (1996). Lektin-Sifat dan Aplikasinya dalam Biologi dan Biomedik. Cermin dunia kedokteran No. 111.

Narayanan. (2004). Insect defence. Its Impact on Microbial Control of Insect Pests. Current science, $86(6), 25$.

Wilson., Chen., Ratcliffe. (1999). Innate Immunity in Insects : The Role of Multiple, Endogenous Serum Lectins in the Recognition of Foreign Invaders in the Cockroach, Blaberus discoidalis. Journal immunol, 162, 1590-1596.

\begin{tabular}{|l|l|}
\hline A.Irma Suryani & $\begin{array}{l}\text { Dosen Jurusan Biologi, Fakultas Matematika dan Ilmu Pengetahuan } \\
\text { Alam. Universitas Negeri Makassar } \\
\text { E-mail: a.irma.suryani@unm.ac.id }\end{array}$ \\
\hline Tjandra Anggraeni & $\begin{array}{l}\text { Jurusan Biologi SITH Institut Teknologi Bandung } \\
\text { E-mail: a.irma.suryani@unm.ac.id }\end{array}$ \\
\hline
\end{tabular}

